\title{
High-resolution measurements of atmospheric molecular hydrogen and its isotopic composition at the West African coast of Mauritania
}

\author{
S. Walter ${ }^{1}$, A. Kock ${ }^{2}$, and T. Röckmann ${ }^{1}$ \\ ${ }^{1}$ Institute for Marine and Atmospheric Research (IMAU), Utrecht University, the Netherlands \\ ${ }^{2}$ Marine Biogeochemistry, GEOMAR/Helmholtz-Centre for Ocean Research, Kiel, Germany
}

Correspondence to: S. Walter (s.walter@uu.nl)

Received: 7 December 2012 - Published in Biogeosciences Discuss.: 19 December 2012

Revised: 17 April 2013 - Accepted: 24 April 2013 - Published: 23 May 2013

\begin{abstract}
Oceans are a net source of molecular hydrogen $\left(\mathrm{H}_{2}\right)$ to the atmosphere, where nitrogen $\left(\mathrm{N}_{2}\right)$ fixation is assumed to be the main biological production pathway followed by photochemical production from organic material. The sources can be distinguished using isotope measurements because of clearly differing isotopic signatures of the produced hydrogen.
\end{abstract}

Here we present the first ship-borne measurements of atmospheric molecular $\mathrm{H}_{2}$ mixing ratio and isotopic composition at the West African coast of Mauritania $\left(16-25^{\circ} \mathrm{W}\right.$, $\left.17-24^{\circ} \mathrm{N}\right)$. This area is one of the biologically most active regions of the world's oceans with seasonal upwelling events and characterized by strongly differing hydrographical/biological properties and phytoplankton community structures. The aim of this study was to identify areas of $\mathrm{H}_{2}$ production and distinguish $\mathrm{H}_{2}$ sources by isotopic signatures of atmospheric $\mathrm{H}_{2}$. For this more than 100 air samples were taken during two cruises in February 2007 and 2008. During both cruises a transect from the Cape Verde Islands towards the Mauritanian Coast was sampled to cover differing oceanic regions such as upwelling and oligotrophic regimes. In 2007, additionally, four days were sampled at high resolution of one sample per hour to investigate a possible diurnal cycle of atmospheric $\mathrm{H}_{2}$.

Our results indicate the influence of local sources and suggest the Banc d'Arguin as a pool for precursors for photochemical $\mathrm{H}_{2}$ production, whereas oceanic $\mathrm{N}_{2}$ fixation could not be identified as a source for atmospheric $\mathrm{H}_{2}$ during these two cruises. The variability in diurnal cycles is probably influenced by released precursors for photochemical $\mathrm{H}_{2}$ production and also affected by a varying origin of air masses. This means for future investigations that only measuring the mixing ratio of $\mathrm{H}_{2}$ is insufficient to explain the variability of an atmospheric diurnal cycle and support is needed, e.g. by isotopic measurements. Nevertheless, measurements of atmospheric $\mathrm{H}_{2}$ mixing ratios, which are easy to conduct online during ship cruises, could be a useful indicator of production areas of biological precursors such as volatile organic compounds (VOCs) for further investigations.

\section{Introduction}

Molecular hydrogen $\left(\mathrm{H}_{2}\right)$ is the second most abundant reduced compound in the atmosphere after methane $\left(\mathrm{CH}_{4}\right)$, with a global average mixing ratio of $\sim 530 \mathrm{ppb}$ and an atmospheric lifetime of $\sim 2 \mathrm{yr}$. $\mathrm{H}_{2}$ is not a radiatively active gas itself, but it contributes significantly to atmospheric chemistry (Novelli et al., 1999; Hauglustaine and Ehhalt, 2002; Rahn et al., 2003; Ehhalt and Rohrer, 2009). By reaction with the hydroxyl radical $(\cdot \mathrm{OH})$, it indirectly influences atmospheric levels and lifetimes of gases that also react with ${ }^{\circ} \mathrm{OH}$, e.g. the strong greenhouse gas $\mathrm{CH}_{4}$ and carbon monoxide $(\mathrm{CO})$ (Prather, 2003; Schultz et al., 2003; Jacobson et al., 2005; Jacobson, 2008). In the stratosphere, oxidation of $\mathrm{H}_{2}$ is a source of water vapor. Water vapor is important for the radiative properties of the stratosphere and also forms the substrate for polar stratospheric clouds, which are key ingredients in the formation of the polar ozone holes (Tromp et al., 2003; Warwick et al., 2004; Feck et al., 2008; Jacobson et al., 2008).

$\mathrm{H}_{2}$ is considered one of the promising future energy carriers, and the shortage, increase in cost and climate impact of fossil fuels leads to increasing interest in alternative energy 
carriers. Numerous studies in the past have addressed the global atmospheric budget of $\mathrm{H}_{2}$. Photooxidation of $\mathrm{CH}_{4}$ and non-methane volatile organic compounds (NM-VOC) in the atmosphere and combustion processes are the main $\mathrm{H}_{2}$ sources, whereas soil deposition and oxidation by ${ }^{\circ} \mathrm{OH}$ are the main sinks. Oceans are a minor but significant source to the global $\mathrm{H}_{2}$ budget with a mean estimated contribution of $7 \%$. However, the range of oceanic contribution from $1 \%$ to $15 \%$ between different studies indicates high uncertainties (Ehhalt and Rohrer, 2009, and references herein, Pieterse et al., 2013).

Oceanic $\mathrm{H}_{2}$ production is assumed to be mainly biological as a by-product of nitrogen $\left(\mathrm{N}_{2}\right)$ fixation (Conrad, 1988). Regarding stoichiometry, the theoretical $\mathrm{H}_{2}$ production is equimolar to the $\mathrm{N}_{2}$ fixation, but due to recycling processes by uptake hydrogenases the production rate is less than the theoretical value and depends on environmental conditions and also on species (Bothe et al., 1980; Tamagnini et al., 2007; Wilson et al., 2010a). Moore et al. (2009) showed recently a strong correlation between the $\mathrm{N}_{2}$ fixation rate and $\mathrm{H}_{2}$ supersaturation in the equatorial Pacific surface waters. Besides $\mathrm{N}_{2}$ fixation, also abiotic photochemical production from chromophoric dissolved organic matter (CDOM) and small organic compounds such as acetaldehyde or syringic acid has been found to be a source of hydrogen in the oceans and should be taken into account (Punshon and Moore, 2008a, and references therein).

However, the temporal and spatial contribution of these processes to the global budget is unclear because of a lack of measurements. To present knowledge, tropical and subtropical surface layers are supersaturated 2 to 3 times with respect to atmospheric $\mathrm{H}_{2}$ concentrations and are a source of hydrogen to the atmosphere, in contrast to temperate and polar surface waters, which are undersaturated in hydrogen (Scranton et al., 1982; Herr et al., 1984, 1981; Herr, 1984; Conrad and Seiler, 1988; Seiler and Schmidt, 1974; Punshon et al., 2007). Vertical profiles display highest mixing ratios in the surface layer with 1 to $3 \mathrm{nmol} \mathrm{L}^{-1}$ and a sharp decrease with depth towards undersaturation, whereas the reasons for undersaturation are not fully understood yet (e.g. Herr et al., 1981; Scranton et al., 1982; Conrad and Seiler, 1988). The $\mathrm{H}_{2}$ production by diazotrophs has been studied intensively and several species show a high potential to produce $\mathrm{H}_{2}$ under natural conditions (e.g. Bothe et al., 2010; Schütz et al., 2004; Wilson et al., 2010a,b; Punshon and Moore, 2008b; Scranton, 1983; Moore et al., 2009), however, the contribution of the different diazotrophs to the marine $\mathrm{H}_{2}$ cycle is unknown. The majority of simultaneous measurements of $\mathrm{N}_{2}$ fixation and $\mathrm{H}_{2}$ production have been conducted on Trichodesmium spp. (Wilson et al., 2010a; Punshon and Moore, 2008b; Scranton et al., 1982), one of the major $\mathrm{N}_{2}$ fixers in the oceans (Capone et al., 2005). Estimates suggest an annual new $\mathrm{N}$ input of at least $1.6 \times 10^{12} \mathrm{~mol} \mathrm{~N}$ to the tropical North Atlantic, which means a substantial fraction of approximately $10-20 \%$ of the global $\mathrm{N}_{2}$ fixation of $100-200 \mathrm{Tg} \mathrm{yr}^{-1}$ (Capone et al., 2005;
Karl et al., 2002; Deutsch et al., 2007), and measurements on $\mathrm{H}_{2}$ production by Trichodesmium indicate that a major part of the dissolved $\mathrm{H}_{2}$ in the ocean is coming from this species, although it cannot account for the total rate of $\mathrm{N}_{2}$ fixation (Wilson et al., 2010a; Punshon and Moore, 2008b; Montoya et al., 2007). Trichodesmium spp. is mostly restricted to tropical regions characterized by warm $\left(>22^{\circ} \mathrm{C}\right)$ surface waters and strong vertical stability (Capone et al., 1997; Tyrrell et al., 2003; Breitbarth et al., 2007), and the eastern tropical North Atlantic is a well-known area for $\mathrm{N}_{2}$ fixation with Trichodesmium spp. considered as one of the dominant species there (Voss et al., 2004; Tyrell et al., 2003; Fernandéz et al., 2010; Davis and McGillicuddy jr., 2006). Besides Trichodesmium, several other $\mathrm{N}_{2}$-fixing organisms like proteobacteria and unicellular cyanobacteria are common in the tropical oceans, and some species are also known for their potential to produce hydrogen (Wilson et al., 2010a; Falcón et al., 2002, 2004; Zehr et al., 2001; Kars et al., 2009; Barz et al., 2010). It is assumed, that $\mathrm{H}_{2}$ production follows a diurnal cycle, but so far published data on dissolved $\mathrm{H}_{2}$ are contradictory. In the oligotrophic South Atlantic, Herr et al. (1984) reported a clear diurnal cycle in the tropical South Atlantic, whereas Conrad and Seiler (1988) in the equatorial Atlantic only found a tendency towards higher $\mathrm{H}_{2}$ mixing ratios in correlation with sunlight. Setser et al. (1982) found a dramatic increase of dissolved $\mathrm{H}_{2}$ mixing ratios when entering warm coastal waters in the northern Pacific and a strong correlation with biological activity, which was not visible in colder open ocean waters. They found no clear daily cycle. Besides this they recalculated data from Bullister et al. (1982), who reported a daily cycle during a CEPEX container experiment. Setser et al. (1982) concluded that there was no positive evidence for a daily cycle of $\mathrm{H}_{2}$. However, laboratory experiments give clear evidence that $\mathrm{H}_{2}$ production can be correlated with sunlight and depends on species, e.g. the biological production by diazotrophs (Wilson et al., 2010a) and also non-biological production by solar degradation of CDOM (Punshon and Moore, 2008a).

Additional information to the global budget and insights in production pathways could come from the analysis of the $\mathrm{H}_{2}$ isotopic composition ( $\left.\delta \mathrm{D}\right)$ (definition see Sect. 2.2). The different sources produce $\mathrm{H}_{2}$ with a very different deuterium content, and also the kinetic fractionation in the two main removal processes, soil deposition and reaction with $\cdot \mathrm{OH}$, is different. This leads to tropospheric $\mathrm{H}_{2}$ which is enriched in deuterium with $\delta \mathrm{D} \sim+130 \%$ (Gerst and Quay, 2001; Rhee et al., 2006a; Rice et al., 2010; Batenburg et al., 2011), whereas surface emissions from fossil fuel combustion and biomass burning have $\delta \mathrm{D}$ values of approximately $-200 \%$ and $-300 \%$, respectively (Gerst and Quay, 2001; Rahn et al., 2002; Röckmann et al., 2010a; Vollmer et al., 2010). As originally proposed by Gerst and Quay (2001) from budget closure, the photochemical sources of $\mathrm{H}_{2}$ are also enriched in deuterium with $\delta \mathrm{D}$ between $\sim+100 \%$ and $+200 \%$ \% (Rahn et al., 2003; Röckmann et al., 2003, 2010b; 

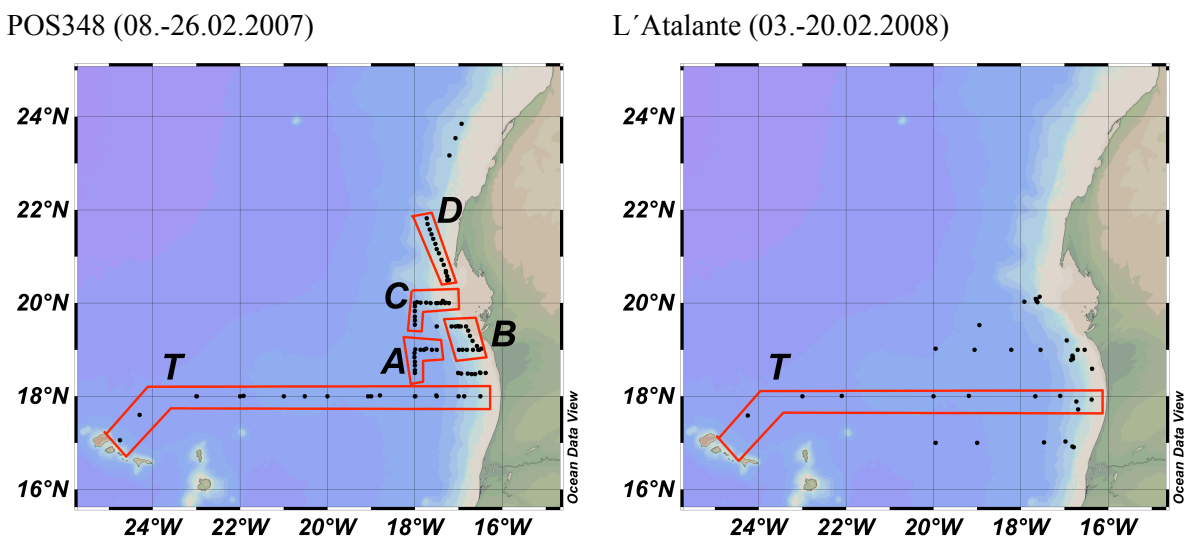

Fig. 1. Sampling positions (black dots) during POS 348 (2007, left) and L'Atalante (2008, right). The labels A to D indicate the four days with high sample resolution during the POS 348 cruise. Each label indicates one day of sampling: A: 20 February 2007, B: 21 February 2007, C: 22 February 2007, and D: 23 February 2007. The label T indicates the transect along $18^{\circ} \mathrm{N}$ (Schlitzer, 2012).

Feilberg et al., 2007; Nilsson et al., 2007, 2010; Pieterse et al., 2009). Biologically produced $\mathrm{H}_{2}$ has the most exceptional isotopic composition with a $\delta \mathrm{D}$ below $-700 \%$ (Walter et al., 2012).

The aim of this study was to examine whether the isotopic signature of atmospheric $\mathrm{H}_{2}$ could be used to identify oceanic areas of expected biological $\mathrm{H}_{2}$ production, which means areas of expected $\mathrm{N}_{2}$ fixation. Based on the up-todate knowledge described previously, we focussed on a tropical region where we could expect $\mathrm{H}_{2}$ emissions probably produced by $\mathrm{N}_{2}$ fixation. Assuming a release of measurable amounts of biologically produced $\mathrm{H}_{2}$, the combination and comparison of hydrographical and biological data together with atmospheric $\mathrm{H}_{2}$ mixing ratios and isotopic signatures should point towards source processes and areas. We took atmospheric samples along a transect from the West African coast off Mauritania towards the open ocean in the direction of the Cape Verde Islands and also in the upwelling region off the Mauritanian coast to cover differing oceanic regions such as upwelling and oligotrophic regimes. Besides this we investigated a possible diurnal cycle of atmospheric $\mathrm{H}_{2}$.

\section{Methods}

\subsection{Study area}

The eastern tropical North Atlantic Ocean between Cape Verde and the Mauritanian coast (see Fig. 1) is characterized by strongly differing hydrographical and biological properties (Kock et al., 2008, and references herein). During late winter and spring, the northeast trade winds induce an intensive seasonal upwelling occurring within a narrow band along the continental margin with typical sea-surface temperatures around or below $17^{\circ} \mathrm{C}$ (Mittelstaedt, 1983; Hagen, 2001). This causes strong gradients between the coastal area and the open ocean towards Cape Verde Islands re- garding nutrient concentration and primary production (Signorini et al., 1999; Minas et al., 1982). Phytoplankton pigment measurements show that the upwelling is characterized by diatoms, whereas cyanobacteria (including Synechococcus, Prochlorococcus, and Trichodesmium) dominate in the oligotrophic open ocean waters west of $18^{\circ} \mathrm{W}$ (Bange, 2008; Zindler et al., 2012).

\subsection{Sampling}

Atmospheric samples were taken onboard the research vessels RV Poseidon (POS 348, 8-26 February 2007) and RV L'Atalante (3-20 February 2008) at the west coast of Mauritania. Both cruises covered a sampling area along the coast of Mauritania and included a transect along $18^{\circ} \mathrm{N}$ towards the Cape Verde Islands (Fig. 1). Samples were taken upwind in $1 \mathrm{~L}$ borosilicate glass flasks at the bridge deck regularly during the cruises. The flasks (NORMAG) are black coated to minimize photochemical reactions inside and sealed with 2 Kel-F (PCTFE) O-ring sealed valves. Storage tests indicate that glass flasks equipped with Kel-F valves are stable for $\mathrm{H}_{2}$ (Rothe et al., 2004; Jordan and Steinberg, 2011). All flasks were previously conditioned by flushing with $\mathrm{N}_{2}$ at $50^{\circ} \mathrm{C}$ for at least $12 \mathrm{~h} . \mathrm{N}_{2}$ remained in the flasks at ambient pressure until the sampling.

During sampling the flasks were flushed for $4 \mathrm{~min}$ with ambient air at a flow rate of $12 \mathrm{~L} \mathrm{~min}^{-1}$ using ${ }^{\circledR}$ Teflon tubes and a membrane pump (KNF VERDER PM2287486 N86ANDC). The sample air was dried with Drierite ${ }^{\circledR}$ $\left(\mathrm{CaSO}_{4}\right)$. The flasks were finally pressurized to approximately 1.7 bar, which allows duplicate measurements for the isotopic composition of an air sample. In total, 40 air samples from the L'Atalante and 75 air samples from the POS 348 were taken. During POS 348 four days were sampled with a high temporal and spatial resolution of one sample per hour at approximately every $30 \mathrm{~km}$ (Fig. 1). 


\subsection{Measurements}

The atmospheric mixing ratio and isotopic composition of molecular $\mathrm{H}_{2}$ were determined using the experimental setup developed by Rhee et al. (2004) and modified as described in Röckmann et al. (2010b). Briefly, the measurements consist of the following steps: (1) An air sample (typically a volume of $\sim 500 \mathrm{~mL}$ at standard temperature and pressure) is exposed to a helium-cooled cold head at $-240^{\circ} \mathrm{C}$, where all gaseous compounds with exception of $\mathrm{H}_{2}$ and some noble gases are condensed; (2) The non-condensed fraction of the sample including $\mathrm{H}_{2}$ is flushed to a preconcentration trap at $-210^{\circ} \mathrm{C}$, consisting of $5 \AA$ molecular sieve in a stainless steel tube $\left(1 / 8^{\prime \prime} \mathrm{OD}\right)$; (3) $\mathrm{H}_{2}$ is released and focused on a capillary gas chromatographic column (filled with molecular sieve $5 \AA$ immersed in liquid nitrogen $\left(-196^{\circ} \mathrm{C}\right)$; (4) the separated $\mathrm{H}_{2}$ is gas chromatographically purified from remaining contaminants at $50^{\circ} \mathrm{C} ;(5)$ the $\mathrm{D} / \mathrm{H}$ ratio of molecular $\mathrm{H}_{2}$ is determined by continuous flow isotope ratio mass spectrometry (IRMS) using a ThermoFinnigan Delta Plus $\mathrm{XL}$ instrument. The $\mathrm{D} / \mathrm{H}$ ratio in a sample is quantified as the relative deviation from the same ratio in a standard, as $\delta \mathrm{D}$ value, and reported in per mille (\%o):

$\delta \mathrm{D}=\frac{[\mathrm{D} / \mathrm{H}]_{\text {sample }}}{[\mathrm{D} / \mathrm{H}]_{\text {standard }}}-1$.

All $\delta \mathrm{D}$ values are reported relative to Vienna Standard Mean Ocean Water (VSMOW). $\mathrm{H}_{2}$ mixing ratios are reported as molar mixing ratios in parts per billion $\left(\mathrm{ppb}=\mathrm{nmol} \mathrm{mol}^{-1}\right.$ ) and linked to the MPI-2009 calibration scale for atmospheric hydrogen (Jordan and Steinberg, 2011). Pure $\mathrm{H}_{2}$ gas was used as running gas for the mass spectrometer. As working standards we used atmospheric air from laboratory reference air bottles and synthetic air mixtures. The atmospheric reference air was collected by the Institute for Environmental Physics (IUP), University of Heidelberg. The $\mathrm{H}_{2}$ mixing ratio was determined by IUP to be $546.2 \pm 2.5 \mathrm{ppb}$ and confirmed by the Max Planck Institute for Biogeochemistry to be $545.0 \pm 0.5 \mathrm{ppb}$. The $\delta \mathrm{D}$ was determined to be $71.4 \pm 2.0 \%$ o, using mixtures of synthetic isotope reference air with $\mathrm{H}_{2}$ of known isotopic composition of $-9.5 \pm 0.5 \%$ o and $+205 \pm 2 \%$, certified by Messer Griesheim, Germany. The atmospheric reference air and the synthetic isotope reference air were measured daily (atmospheric reference air at least twice), and results were used for correction of the sample measurements. The given errors are random (i.e. reproducibility) errors only and do not include possible systematic errors (Batenburg et al., 2011; Walter et al., 2012). Samples were measured randomly and within less than 15 weeks after collection, and for both sample sets (2007 and 2008) the same standards were used (atmospheric reference air and synthetic isotope reference air).

To determine the overall mean reproducibility, several samples were measured twice. The average reproducibility was $6.5 \mathrm{ppb}$ for $\mathrm{H}_{2}$ mixing ratio and $2.5 \%$ for $\delta \mathrm{D}$ for the
POS $348(n=19)$, and respectively $7.2 \mathrm{ppb}$ and $5.0 \%$ for the L'Atalante $(n=7)$.

Meteorological and oceanographic parameters (radiation, air and water temperatures, salinity, relative humidity) were measured using standard instrumentation, and recorded and provided by the data systems of the ships. More information about devices and sensor documentation can be found on the website of the Alfred Wegener Institute, http://dship.awi.de/, and Ifremer, the French Research Institute for Exploration of the Sea, http://flotte.ifremer.fr. For each sample a backward Hybrid Single Particle Lagrangian Integrated Trajectory (HYSPLIT) was calculated (Draxler and Rolph, 2013; http://ready.arl.noaa.gov/HYSPLIT.php).

\section{Results and discussion}

\subsection{Transect along $18^{\circ} \mathrm{N}$ from the Cape Verde Islands toward the West African coast of Mauritania}

Sea surface temperatures (SST) ranged from $16.16^{\circ} \mathrm{C}$ at the Mauritanian coast to $22.74^{\circ} \mathrm{C}$ near Cape Verde in 2007 and $17.70^{\circ} \mathrm{C}$ and $22.10^{\circ} \mathrm{C}$ in 2008 , respectively, and indicate upwelling during both cruises (Mittelstaedt, 1983). During both cruises phytoplankton pigments were measured. The results show for both years that the upwelling is characterized by diatoms, whereas cyanobacteria (including Synechococcus, Prochlorococcus, and Trichodesmium) dominate in the oligotrophic open ocean waters west of $18^{\circ} \mathrm{W}$ (Bange, 2008; Zindler et al., 2012).

Figure 2 shows the $\mathrm{H}_{2}$ mixing ratio (Fig. 2a) and the isotopic composition $\delta \mathrm{D}$ (Fig. 2b) along the $18^{\circ} \mathrm{N}$ transect between Cape Verde Islands and the west coast of Mauritania during the two cruises. In this and all subsequent figures, green symbols indicate the cruise with RV Poseidon in February 2007 and red symbols the cruise with RV L'Atalante in February 2008. The mean $\mathrm{H}_{2}$ mixing ratio in 2008 was $549 \pm 7 \mathrm{ppb}$, but without a clear difference between the open ocean and upwelling area. In 2007 the $\mathrm{H}_{2}$ mixing ratio was $507 \pm 6.5 \mathrm{ppb}$ near the coast of Mauritania and changed significantly towards the open ocean by an increase of about $20 \mathrm{ppb}$. $\delta \mathrm{D}$ shows values between $+110 \%$ o and $+130 \%$ with generally slightly higher values in 2007 . However, during both cruises no significant depletion in the isotopic ratio towards the open ocean was found, neither in 2007 nor in 2008. There is actually a tendency of increasing $\delta \mathrm{D}$ values towards the open ocean during both cruises, but these variations are within the range of measurement uncertainties. Monthly measurements of $\mathrm{H}_{2}$ mixing ratio and $\delta \mathrm{D}$ as part of the EUROHYDROS project (Batenburg et al., 2011) from the Cape Verde observation tower $\left(24^{\circ} 87 \mathrm{~W}, 16^{\circ} 85 \mathrm{~N}\right)$ reveal an atmospheric $\mathrm{H}_{2}$ background close to our results near this position (Fig. 2).

To interpret the $\mathrm{H}_{2}$ concentration gradient in 2007, different scenarios are conceivable. We can assume either (I) an 
a)

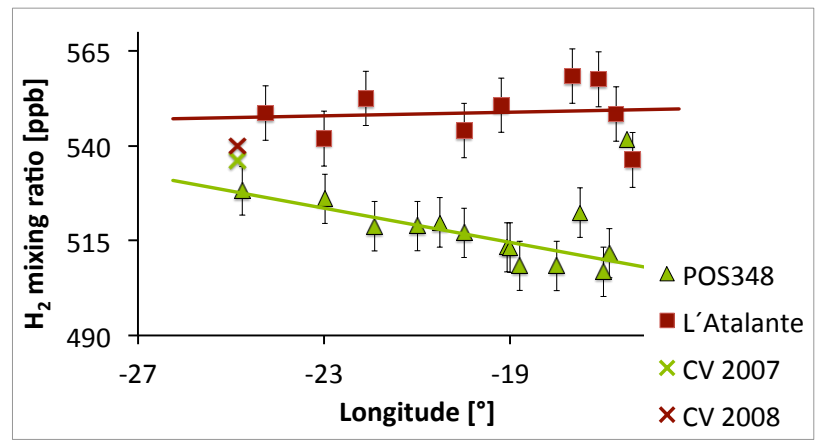

b)

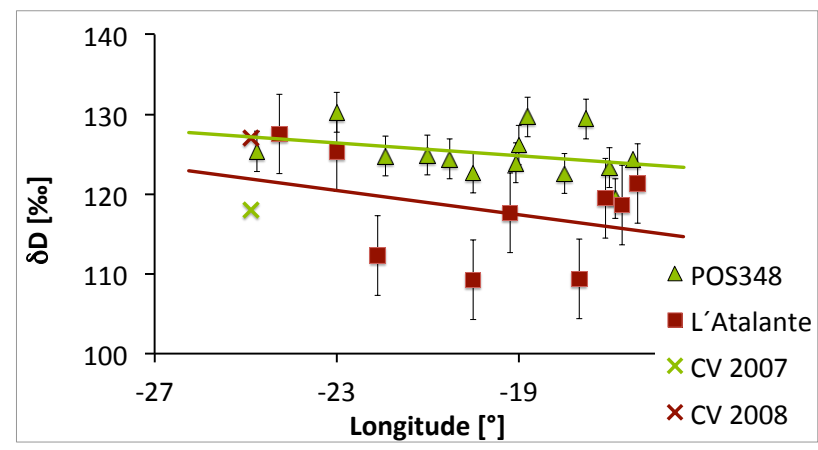

Fig. 2. $\mathrm{H}_{2}$ mixing ratio (ppb) and $\delta \mathrm{D}\left(\%\right.$ o) along the $18^{\circ} \mathrm{N}$ transect between the Cape Verde Islands and the West African coast in 2007 (green labeled) and 2008 (red labeled). The error bars indicate the average reproducibility. The crosses (CV 2007 and CV 2008) indicate the monthly measurement results from the Cape Verde observation tower $\left(24^{\circ} 87 \mathrm{~W}, 16^{\circ} 85 \mathrm{~N}\right)$ closest to the sampling period (29 March 2007, and 8 February 2008). The Cape Verde measurements were part of the EUROHYDROS project (Batenburg et al., 2011). (a) $\mathrm{H}_{2}$ mixing ratio (ppb): RV Poseidon (2007): $-2.25 x+472, n=13, r=0.79$; RV L'Atalante (2008): $0.24 x+553, n=9, r=0.10$. (b) Isotopic composition $\delta \mathrm{D}(\%)$ : RV Poseidon (2007): $-0.40 x+117, n=13, r=0.31$; RV L'Atalante (2008): $-0.76 x+103, n=9, r=-0.35$.

increase towards the Cape Verde in 2007 caused by sources, (II) a decrease in mixing ratio towards the coast caused by sinks, or (III) an increase/decrease due to mixing of air masses, or a combination of them.

Previous studies showed that biologically produced $\mathrm{H}_{2}$ released from aquatic systems is extremely depleted with $\delta \mathrm{D}$ values below $-700 \%$ independent of species and probably from uptake/recycling within the system (Walter et al., 2012). This means that biologically produced and emitted $\mathrm{H}_{2}$ is expected to be approximately $800 \%$ o depleted relative to the ambient $\mathrm{H}_{2}$ reservoir, and therefore, an increase of $1 \%$ in the $\mathrm{H}_{2}$ mixing ratio would result in a $8 \%$ o lower $\delta \mathrm{D}$ value. In 2007 , the mixing ratio increased by $3 \%$ towards the open ocean, and if this amount were produced via $\mathrm{N}_{2}$ fixation, a significant decrease of the isotopic signal of approximately $24 \%$ would be expected. An isotopic fractionation during the release to the atmosphere is possible and probable, but would change this result by less than $2 \%$ (Knox et al., 1992; Muccitelli and Wen, 1978; Vignais, 2005) and is therefore negligible for the overall picture. Thus, a significant contribution due to $\mathrm{N}_{2}$ fixation can be excluded.

Punshon and Moore (2008) showed that photochemical production is possible, and gave a $\mathrm{H}_{2}$ formation rate of $37 \mathrm{pmol} \mathrm{H}_{2} \mathrm{~L}^{-1} \mathrm{~h}^{-1}$ in coastal waters, which is 4 to 5 times lower than in lake water. The formation rates are positively correlated with CDOM concentrations and the products of its photo-degradation. Given that CDOM concentrations in the oligotrophic ocean may be an order of magnitude lower than in coastal regions (Punshon and Moore, 2008; Siegel et al., 2002 ), production in the open ocean should be much lower. No correlation between the mixing ratio and the radiation was found.

The isotopic signature of photochemically produced $\mathrm{H}_{2}$ is expected to be between $\sim+100 \%$ and $+200 \%$ (Rahn et al., 2003; Röckmann et al., 2003, 2010b; Rhee et al., 2006a, b; Feilberg et al., 2007; Nilsson et al., 2007, 2010; Pieterse et al., 2009), and a Keeling plot analysis of our results reveals a source signature slightly above this range $(+218 \%$ ), although with high uncertainties. We therefore cannot exclude a contribution of photochemically produced $\mathrm{H}_{2}$; however, due to the low expected formation rates and the fact that $\mathrm{H}_{2}$ increases towards the open ocean, a strong photochemical contribution to the atmospheric $\mathrm{H}_{2}$ mixing ratio along this transect seems unlikely.

$\mathrm{H}_{2}$ removal could be explained by two sink processes: the reaction with ${ }^{\circ} \mathrm{OH}$ and dry deposition to the soil. The oxidation of $\mathrm{H}_{2}$ by ${ }^{\circ} \mathrm{OH}$ is slow and cannot explain a fast regional decrease of $20 \mathrm{ppb}$. Dry deposition to the soil is the most important sink for atmospheric $\mathrm{H}_{2}$, and it is reasonable to assume that contact with the land surface led to a significant decrease in $\mathrm{H}_{2}$ mixing ratio (Smith-Downey et al., 2008; Rhee et al., 2006b; Ehhalt and Rohrer, 2009). Figure 3 shows $120 \mathrm{~h}$ backward trajectories for the most eastern and the most western position sampled during these $18^{\circ} \mathrm{N}$ transects, and one in between. The trajectories were performed using the NOAA HYSPLIT model (http://www.arl.noaa.gov/ ready/hysplit4.html), and the ones shown here are representative for the whole transect. The air mass back trajectories revealed clear differences between the two cruises regarding the origin of wind: in 2008 wind came exclusively from the oceanic sector for at least three to four days before sampling, ranging from $324^{\circ}$ to $33^{\circ}$ and with a mean wind speed of $15.3 \pm 4.2 \mathrm{~m} \mathrm{~s}^{-1}$. In contrast, in 2007 the wind came mainly from the northeast over land, crossing Morocco and Mauritania, in some cases also Algeria, in a range of $341^{\circ}$ to $65^{\circ}$ and with a mean wind speed of $9.9 \pm 2.3 \mathrm{~m} \mathrm{~s}^{-1}$. Based on this we conclude that the lower concentrations measured 2007 near the Mauritanian coast are likely a result of soil deposition. During the subsequent transport over the ocean toward the Cape Verde Islands, the $\mathrm{H}_{2}$ mixing ratio increases due to mixing with air that had less contact with the land surface 
a) Backward trajectories 2007
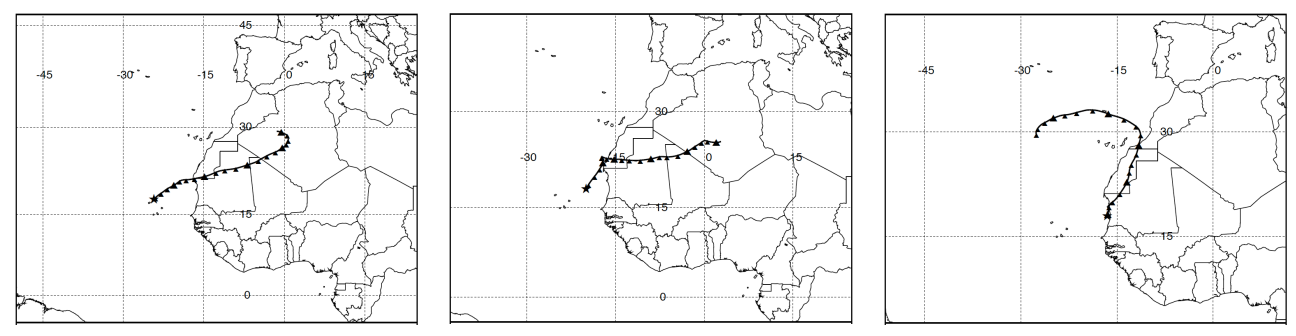

b) Backward trajectories 2008
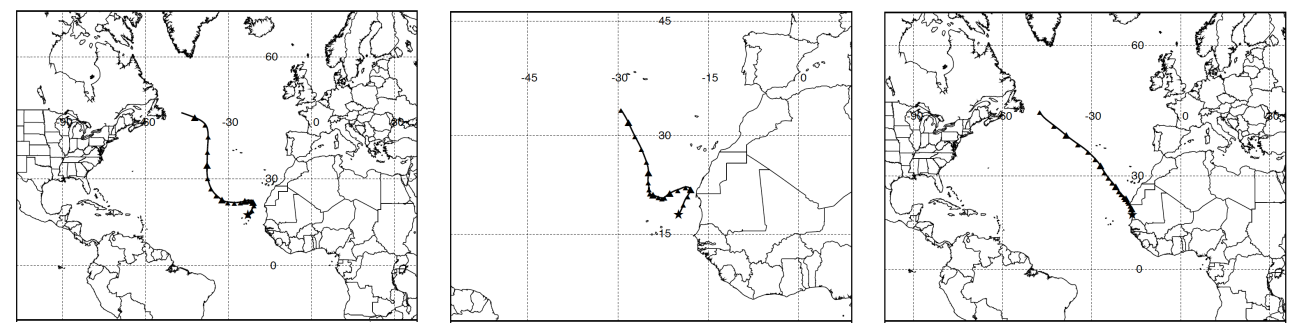

http://ready.arl.noaa.gov/HYSPLIT_traj.php

Fig. 3. Backward trajectories (HYSPLIT), $120 \mathrm{~h}$ for representative sampling locations along the $18^{\circ} \mathrm{N}$ transect: (a) POS 348 (2007) and (b) L'Atalante (2008).

and show $\mathrm{H}_{2}$ background mixing ratios. Thus, the mixing ratio gradient between the Cape Verde Islands and the west coast of Mauritania is likely a result of dry deposition during transport over land and mixing with $\mathrm{H}_{2}$ enriched ambient air masses during transport over sea. The isotopic ratio measurements support this scenario. The fractionation factor for soil uptake is small, $\alpha=0.94$ (Gerst and Quay, 2001), and the expected $\delta \mathrm{D}$ enrichment for the observed change in mixing ratio is only 2 to $3 \%$. These values are within the range of measurement uncertainty and can explain why no clear $\delta \mathrm{D}$ gradient was found. A Rayleigh analysis of our data gives an $\alpha=0.88 \pm 0.03(n=12, r=0.39)$.

In 2008 , mixing ratios are generally higher compared to 2007, close to background concentrations, and no trend neither in signature nor mixing ratio was observed. The wind came from the Atlantic for at least 3 to 4 days before sampling, without transport of air over land. Therefore we conclude that the results from 2008 represent remote oceanic conditions for $\mathrm{H}_{2}$ without a soil sink signal such as during the POS 348 cruise in 2007.

\subsection{Spatial and temporal high-resolution sampling at the Mauritanian coast}

During all days the general weather conditions were stable without significant differences between the days (Table 1). All days were sunny and cloudless with maximum global radiation of 844 to $892 \mathrm{~W} \mathrm{~m}^{-2}$. The wind blew stable from NNW $\left(341^{\circ}\right)$ to $\mathrm{NE}\left(65^{\circ}\right)$ directions with wind speeds between 6 and $15 \mathrm{~m} \mathrm{~s}^{-1}$. In the morning wind came more from eastern directions, shifting to the north during the day. HYSPLIT trajectories reveal a common origin of the air masses for the previous $24 \mathrm{~h}$ without significant intrusions from higher altitudes (tested height of air masses $20 \mathrm{~m}, 500 \mathrm{~m}$ and $1000 \mathrm{~m}$ ). The mean atmospheric mixed layer depth was approximately $500 \mathrm{~m}$, with a range between 300 and $800 \mathrm{~m}$.

To investigate a possible diurnal cycle, atmospheric $\mathrm{H}_{2}$ mixing ratios from the high resolution sampling periods are compared to radiation in Fig. 4. Similar to previous published data on diurnal cycles of dissolved $\mathrm{H}_{2}$, our results for the four days do not show a consistent picture. During the four highresolution sampled days in 2007, the atmospheric $\mathrm{H}_{2}$ mixing ratio showed a range of $473 \mathrm{ppb}$ to $563 \mathrm{ppb}$, and $\delta \mathrm{D}$ ranged from $107 \%$ o to $135 \%$ o (Table 1).

All days started with a mean background mixing ratio between 500 and $520 \mathrm{ppb}$. The first two days (Fig. 4a, b) show a clear positive correlation between the two parameters. While the increase in $\mathrm{H}_{2}$ mixing ratio was moderate (about $17 \mathrm{ppb}$ ) during the first day, the increase during the second day was surprisingly high (about $61 \mathrm{ppb}$ ). For both days, no clear trend in $\delta \mathrm{D}$ was detectable. The positive correlation between mixing ratio and radiation was not observed for the third and fourth day (Fig. 4c, d). Here we found no clear correlation with slightly decreasing mixing ratios of $9 \mathrm{ppb}$ on 22 February (Fig. 4c) and a negative correlation with a decrease of $\mathrm{H}_{2}$ mixing ratio of $44 \mathrm{ppb}$ on 23 February (Fig. 4d), respectively. This negative correlation is parallel shifted in the evening to higher mixing ratios. On day 4 , an increase in $\delta$ D of $25 \%$ o from $107 \%$ (07:24 UTC) to $132 \%$ (15:04 UTC) was observed, positively correlated with radiation. 
a) 20.02.2007

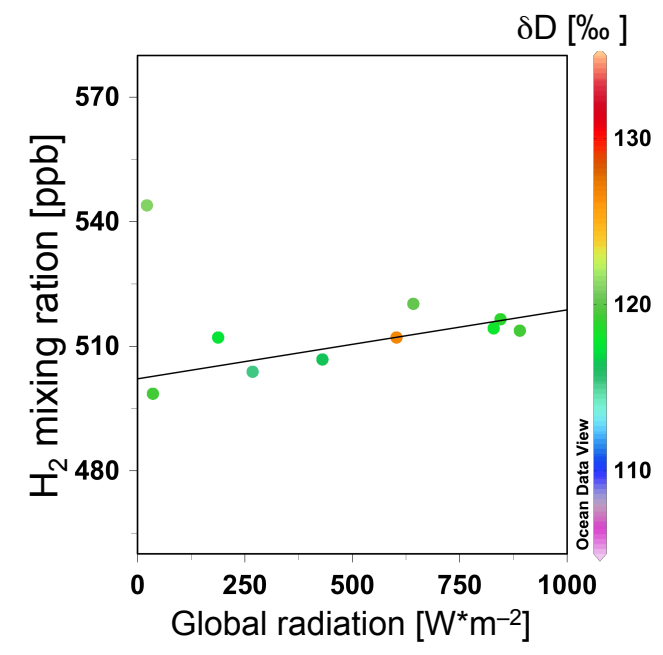

c) 22.02 .2007

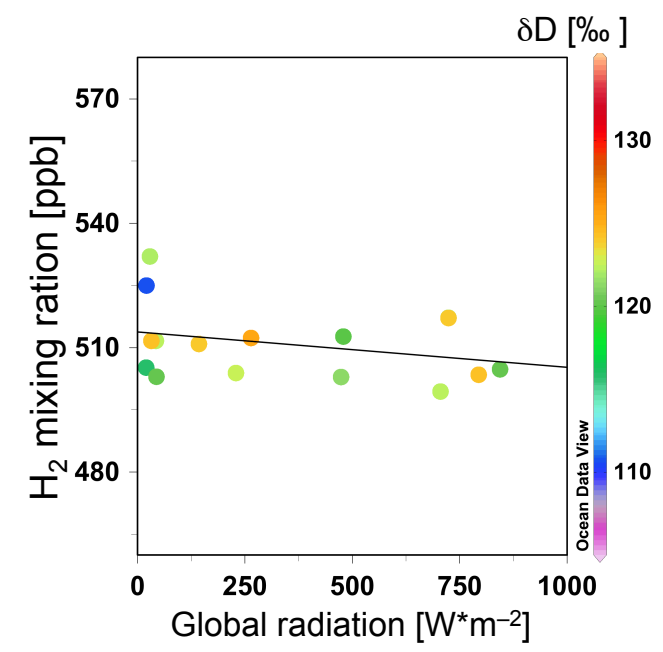

b) 21.02 .2007

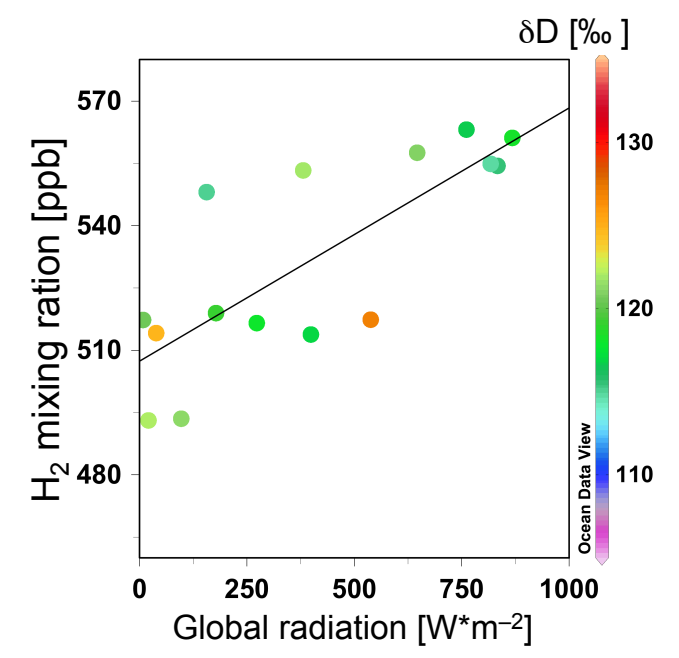

d) 23.02 .2007

Fig. 4. Correlation between $\mathrm{H}_{2}$ mixing ratio (ppb) and radiation $\left(\mathrm{W} \mathrm{m}^{-2}\right)$ with color-coded $\delta \mathrm{D}(\%)$ during the four high-resolution sampled days 2007. (a): 20 February 2007, excluding 1 outlier (07:31 UTC), $y=0.0167 x+502.14, r=0.771, n=9$; (b): 21 February 2007, $y=0.061 x+507.38, r=0.784, n=15$; (c): 22 February 2007, $y=-0.009 x+513.79, r=-0.311, n=16$; and (d): 23 February 2007, $y=-0.044 x+517.04, r=-0.618, n=11$ (Schlitzer, 2012).

Table 1. Sampling location and weather conditions during the four high-resolution sampled days (POS 348, 2007).

\begin{tabular}{|c|c|c|c|c|c|c|c|c|c|c|c|}
\hline Date & Location & $\begin{array}{c}\text { Sampling } \\
\text { time (UTC) }\end{array}$ & $n$ & $\begin{array}{c}\text { Range } \mathrm{H}_{2} \\
\text { [ppb] }\end{array}$ & $\begin{array}{c}\text { Range } \delta \mathrm{D} \\
{[\% o]}\end{array}$ & $\begin{array}{l}\text { Humidity } \\
(\%)\end{array}$ & $\begin{array}{l}\text { Radiation } \\
{\left[\mathrm{W} \mathrm{m}^{-2}\right]}\end{array}$ & Salinity & $\operatorname{SST}\left({ }^{\circ} \mathrm{C}\right)$ & $\begin{array}{c}\text { Wind } \\
\text { direction }\left({ }^{\circ} \mathrm{N}\right)\end{array}$ & $\begin{array}{c}\text { Wind } \\
\text { speed }\left(\mathrm{m} \mathrm{s}^{-1}\right)\end{array}$ \\
\hline 20 Feb 2007 & $\begin{array}{l}18.0^{\circ} \mathrm{W}, 18.5^{\circ} \mathrm{N}- \\
17.5^{\circ} \mathrm{W}, 19.0^{\circ} \mathrm{N}\end{array}$ & $07: 38-21: 15$ & 10 & $499-544$ & $115-127$ & $69-80$ & 890 & $35.83-36.00$ & $18.8-20.0$ & $349-36$ & $9.3-15.3$ \\
\hline 21 Feb 2007 & $\begin{array}{l}17.0^{\circ} \mathrm{W}, 19.0^{\circ} \mathrm{N}- \\
17.2^{\circ} \mathrm{W}, 19.5^{\circ} \mathrm{N}\end{array}$ & $06: 31-20: 30$ & 15 & $493-563$ & $115-127$ & $45-82$ & 868 & $35.56-35.89$ & $16.2-18.3$ & $341-60$ & $6.1-12.3$ \\
\hline 22 Feb 2007 & $\begin{array}{l}18.0^{\circ} \mathrm{W}, 19.5^{\circ} \mathrm{N}- \\
17.2^{\circ} \mathrm{W}, 20.0^{\circ} \mathrm{N}\end{array}$ & $07: 03-22: 24$ & 16 & $499-532$ & $110-125$ & $66-81$ & 844 & $35.57-36.12$ & $17.2-18.6$ & $344-35$ & $7.0-12.0$ \\
\hline 23 Feb 2007 & $\begin{array}{l}17.3^{\circ} \mathrm{W}, 20.4^{\circ} \mathrm{N}- \\
17.7^{\circ} \mathrm{W}, 21.8^{\circ} \mathrm{N}\end{array}$ & $07: 24-21: 10$ & 11 & $473-549$ & $107-135$ & $68-82$ & 892 & $36.04-36.35$ & $17.4-18.2$ & $1-44$ & $6.4-13.4$ \\
\hline
\end{tabular}


a) radiation $\left[\mathrm{W}^{*} \mathrm{~m}^{-2}\right]$

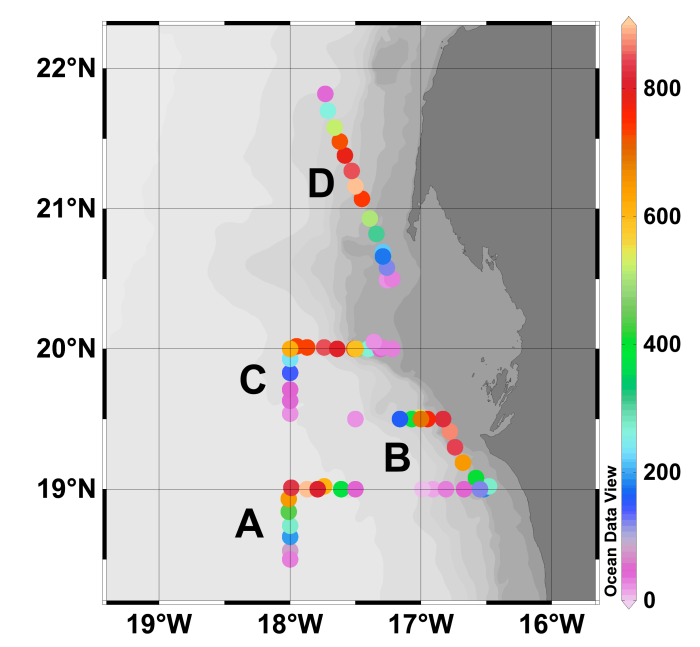

c) $\mathrm{H}_{2}$ mixing ratio $[\mathrm{ppb}]$

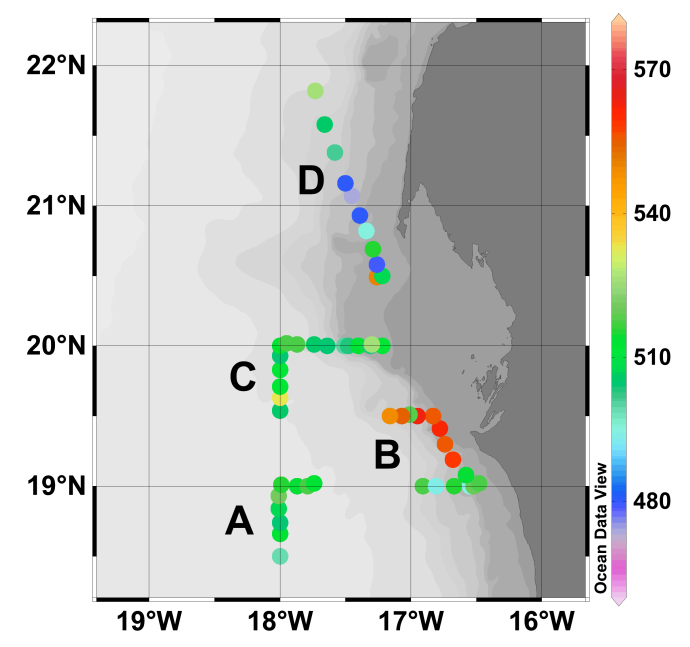

b) wind direction $\left[^{\circ}\right]$

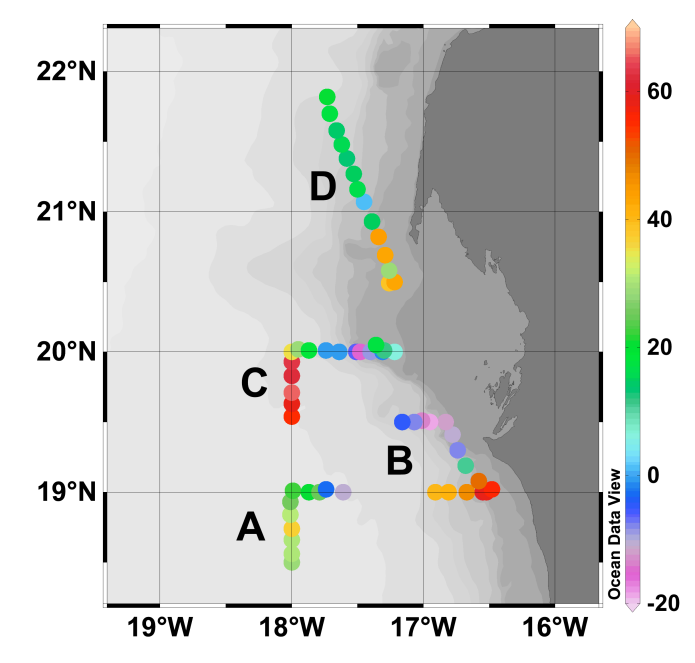

d) $\delta \mathrm{D}[\% \circ]$

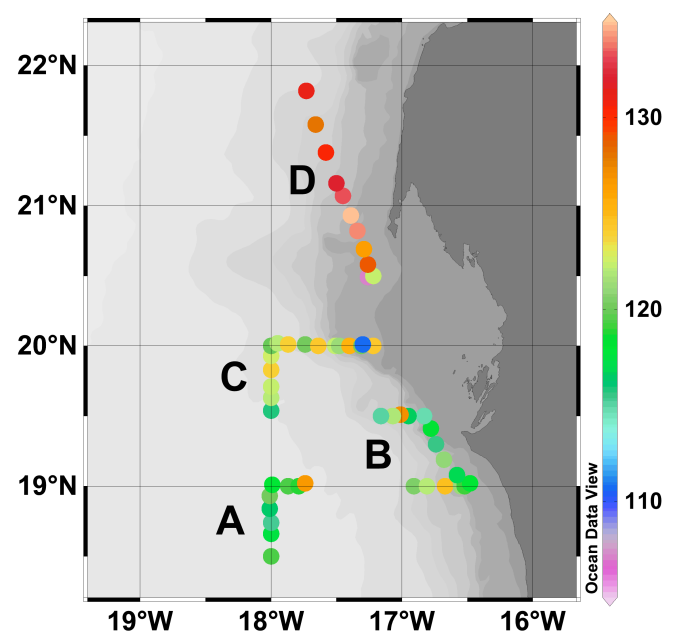

Fig. 5. Sampling positions with color-coded results for (a) radiation $\left(\mathrm{W} \mathrm{m}^{-2}\right)$, (b) wind direction $\left(^{\circ}\right)$, (c) $\mathrm{H}_{2}$ mixing ratio (ppb), and (d) $\delta \mathrm{D}(\%)$. The labels in each subfigure A to D indicate the days of high-resolution sampling: A: 20 February 2007, B: 21 February 2007, C: 22 February 2007, and D: 23 February 2007. Note: the wind direction is given in a range from $-180^{\circ}$ to $180^{\circ}$ to give a better resolution $\left(0^{\circ}\right.$ means wind coming from northern directions; Schlitzer, 2012).

Intrusion of air masses from a higher altitude and contamination by biomass burning or anthropogenic sources are conceivable sources for enhanced $\mathrm{H}_{2}$ mixing ratios during the first two days, but both are unlikely in this case due to the following reasons:

i. The weather conditions were stable for all days, with no intrusion from higher altitudes. In addition, typical vertical variability in the mixing ratio is not sufficient to explain such high variations in mixing ratio found here (Schmidt, 1978; Hauglustaine and Ehhalt, 2002; Pieterse et al., 2011). ii. The wind during sampling and the days before came from northern directions; biomass burning is expected to occur further south. Due to similar wind directions and velocities, this signature would probably be visible during all days. This applies also for anthropogenic sources.

iii. The isotope values do not support the possibility of enhanced mixing ratios due to biomass burning or anthropogenic sources. Both sources show distinctly depleted $\delta$ D values of approximately -200 to $-300 \%$ (Gerst and Quay, 2001). A contribution of more than $60 \mathrm{ppb}$ from these sources to the observed $\mathrm{H}_{2}$ mixing ratio would result in a significant decrease of $\delta \mathrm{D}$ of approximately $40-50 \%$. 


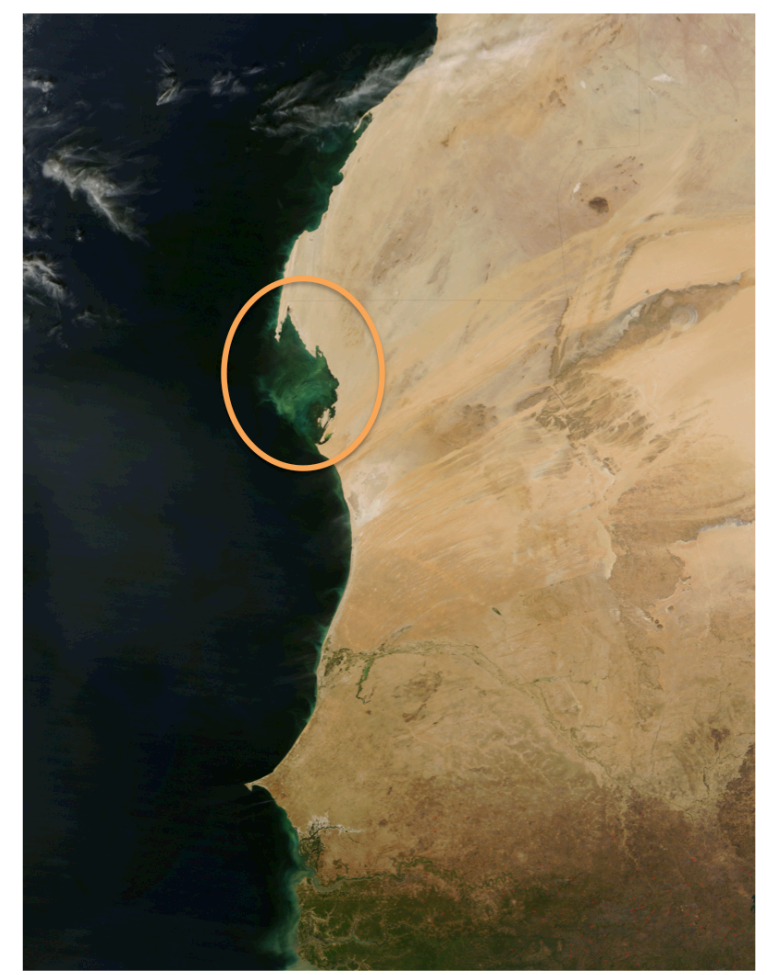

Fig. 6. MODIS picture of the west Mauritanian coast, 2006. Note: the circled area indicates the Banc d'Arguin (http://earthobservatory.nasa.gov/IOTD/view.php?id=7240).

For these reasons we exclude biomass burning and fossil fuel combustion as major contributors to explain the increase in $\mathrm{H}_{2}$ mixing ratio during the first two days. The hypothesis of $\mathrm{H}_{2}$ release as a byproduct of nitrogen fixation is also not supported by our data as well. Biologically produced hydrogen with a $\delta \mathrm{D}$ value of less than $-700 \%$ (Walter et al., 2012) would result in an even more depleted signal than for biomass burning and fossil fuel combustion.

The strongest diurnal variation is observed on the second day. Detailed analysis of the variations of mixing ratios and $\delta \mathrm{D}$ with wind direction (see Fig. 5) shows that the second day is split in two periods by the small, typical daily shifts in wind direction: after noon the wind came more from $\mathrm{N}$ to NNW directions and the data show higher $\mathrm{H}_{2}$ mixing ratios $(556 \mathrm{ppb} \pm 5, n=7)$ and slightly lower $\delta \mathrm{D}(117 \% \circ \pm 3$, $n=7$ ), while wind from NE in the morning is associated with lower mixing ratios $(511 \mathrm{ppb} \pm 11, n=8)$ and higher $\delta \mathrm{D}(121 \% \circ \pm 3, n=8)$. Wind from NE directly came from the African continent, while wind from the more northern directions crossed the Banc d'Arguin.

The Banc d'Arguin (see circled area in Fig. 6), a national park and UNESCO World Heritage Site, is a largescale negative estuary with no or scant river discharge and increasing water densities towards the land. The park covers an area of over $10000 \mathrm{~km}^{2}$ of shallow water and tidal flats between the Sahara and the upwelling system off the
Mauritanian coast. Its eutrophic ecosystem is highly productive and dominated by a detritus-based benthic food web in which seagrasses (Zostera noltii, Cymodocea nodosa, Halodule wrightii) are the principal primary producers, followed by several species of seaweeds. A mangrove swamp (3.100 ha) is a relict of a previous humid geological period (Monod, 1977; Schaffmeister et al., 2006; Dahdouh-Guebas and Koedam, 2001; Wolff et al., 1993; Sevrin-Reyssac, 1993).

Punshon and Moore (2008a) showed that $\mathrm{H}_{2}$ could be produced non-biologically by photochemical reactions, potentially from low-molecular-weight molecules associated with chromophoric dissolved organic matter (CDOM), e.g. syringic acid or to a minor extent acetaldehyde. Syringic acid is one of the most common monophenols to be released during the degradation of lignin (Thoss et al., 2002), which is one of the major constituents of seagrasses and trees such as mangroves (Bourgues et al., 1996; Torbatinejad et al., 2007; Klap et al., 2000),

The largest source of atmospheric acetaldehyde is thought to be photochemical degradation of volatile organic compounds (VOCs), e.g. isoprene (Millet et al., 2010). Both isoprene and acetaldehyde are emitted from the ocean, e.g. from seaweeds (Broadgate et al., 2004), correlating with light and phytoplankton abundance (Sinha et al., 2007; Zepp et al., 1998). The lifetime of acetaldehyde is approximately one day, and diurnal cycles are known for several low-molecularweight carbonyl compounds, not only acetaldehyde but also formaldehyde (Singh et al., 2004; Zhou and Mopper, 1997). Until now the global budget of these reactive trace gases is highly uncertain and no information about the isotopic composition of photochemically produced $\mathrm{H}_{2}$ from nonmethane hydrocarbons (NMHC) exist, although a contribution of $\sim 20 \%$ to the total photochemical production is estimated (see Ehhalt and Rohrer, 2009, Pieterse et al., 2011, and references herein). For global models a $\delta \mathrm{D}$ of $+162 \%$ is assumed (Rice et al., 2010), and recently Pieterse et al. (2011) calculated a $\delta \mathrm{D}$ value of $+116 \%$. Keeling plot analyses of the first two days give a mean source signature of $98 \%$, within a range of $82 \%$ to $265 \%$, depending on spatial or temporal clustering of the data. These data clearly exclude biological sources as the main contributors to the observed results and support the hypothesis of photochemical production. The data suggest that large amounts of precursors for photochemical production of $\mathrm{H}_{2}$ may be emitted from the Banc d'Arguin and that the subsequent photochemical production may cause the observed $\mathrm{H}_{2}$ increase during the second day. As the wind direction changes in a similar way, this could also explain the results of the first and third day.

The same pattern as of the second day was also found for dissolved and atmospheric $\mathrm{CH}_{4}$ (Kock et al., 2008, and additional unpublished data). Although in this study the water column was supersaturated with $\mathrm{CH}_{4}$, the emissions from surface waters were not considered sufficient to explain the 
full increase in mixing ratios. Therefore, the authors also assumed a possible contribution from the Banc d'Arguin.

During the fourth day we observed a decrease in mixing ratio of $44 \mathrm{ppb}$ (Fig. 4d), which is negatively correlated with radiation and parallel shifted to higher mixing ratios in the evening. The $\delta \mathrm{D}$ values increased in the mean by about $13 \%$, positively correlated with radiation. As argued above, the oxidation of $\mathrm{H}_{2}$ by $\cdot \mathrm{OH}$ is slow and cannot explain the decrease of $44 \mathrm{ppb}$ during the day. A decrease in mixing ratio of $44 \mathrm{ppb}$ mainly due to soil deposition would result in an increase of isotopic ratios of approximately $9 \%$, which fits with our results. The HYSPLIT model reveals stable wind from on-shore, with a shallow mixed layer depth and no intrusions of air masses from higher altitudes. During the day the wind shifts slightly towards the open ocean. This results in a shorter transport time over land and might explain the slight shift of correlation towards higher mixing ratios and lower delta values because of less deposition. A Rayleigh analysis gives an $\alpha=0.89(n=11, r=-0.77)$ and supports this hypothesis.

Therefore we suggest that the decrease in mixing ratio combined with the slight increase of isotopic signature is probably related to the soil sink and mixing with remote air, comparable to the results of the $18^{\circ} \mathrm{N}$ transect.

\section{Conclusions}

The aim of this study was to identify areas of $\mathrm{H}_{2}$ production and distinguish $\mathrm{H}_{2}$ sources by isotopic signatures of atmospheric $\mathrm{H}_{2}$. Besides this, a diurnal cycle of atmospheric $\mathrm{H}_{2}$ was investigated. A biological source of atmospheric $\mathrm{H}_{2}$ such as $\mathrm{N}_{2}$ fixation could not be identified by isotopic measurements, although Cyanobacteria (including Trichodesmium) have been shown to be one of the dominant species in the region outside the upwelling area. The data indicate that probably photochemical sources in biologically active areas such as the Banc d'Arguin play an important role, and suggest that these areas may release significant amounts of precursors, which are then photochemically degraded and produce $\mathrm{H}_{2}$.

The variability in diurnal cycles is probably influenced by released precursors for photochemical $\mathrm{H}_{2}$ production and also affected by a varying origin of air masses. This means for further investigations that only measuring the mixing ratio of $\mathrm{H}_{2}$ is insufficient to explain the variability of an atmospheric diurnal cycle and support is needed, for example, by isotopic measurements. However, measurements of $\mathrm{H}_{2}$ mixing ratios, which are easy to conduct online during ship cruises, could be a useful indicator of production areas of biological precursors such as volatile organic compounds for further investigations. Considering the size and the importance of the oceans for trace gases, the ocean's influence is poorly understood.
Acknowledgements. We would like to thank the crew of the RV Poseidon and the RV L'Atalante for their friendly help and support, and special thanks to Klaus Buldt from the DWD (Deutscher Wetterdienst). This study was financed by the NWO (Netherlands Organization for Scientific Research), NWO project number 816.01.001, and supported by the BMBF grant SOPRAN FKZ 03F0462A (AK). The authors also gratefully acknowledge the NOAA Air Resources Laboratory (ARL) for the provision of the HYSPLIT transport and dispersion model and/or READY website (http://ready.arl.noaa.gov) used in this publication.

Edited by: G. Herndl

\section{References}

Bange, H. W.: FS Poseidon cruise report P348: SOPRAN, Mauritanian upwelling study 2007, Las Palmas - Las Palmas, 08.02.26.02.2007, IFM-GEOMAR report 18; Kiel, doi:10.3289/ifmgeomar_rep_18_2008, 2008.

Barz, M., Beimgraben, C., Staller, T., Germer, F., Opitz, F., Marquardt, C., Schwarz, C., Gutekunst, K., Vanselow, K. H., Schmitz, R., LaRoche, J., Schulz, R., and Appel, J.: Distribution analysis of hydrogenases in surface waters of marine and freshwater environments, PLoS ONE, 5, e13846, doi:10.1371/journal.pone.0013846, 2010.

Batenburg, A. M., Walter, S., Pieterse, G., Levin, I., Schmidt, M., Jordan, A., Hammer, S., Yver, C., and Röckmann, T.: Temporal and spatial variability of the stable isotopic composition of atmospheric molecular hydrogen: observations at six EUROHYDROS stations, Atmos. Chem. Phys., 11, 6985-6999, doi:10.5194/acp11-6985-2011, 2011.

Bothe, H., Neuer, G., Kalbe, I., and Eisbrenner, G.: Electron donors and hydrogenase in nitrogen-fixing microorganisms, in: Stewart WDP, edited by: Gallon J. R., Nitrogen fixation. Academic Press, London, 83-112, 1980.

Bothe, H., Schmitz, O., Yates, M. G., and Newton, W. E.: Nitrogen fixation and hydrogen metabolism in cyanobacteria, Microbiol. Mol. Biol. Rev., 74, 529-51, doi:10.1128/MMBR.0003310, 2010.

Breitbarth, E., Oschlies, A., and LaRoche, J.: Physiological constraints on the global distribution of Trichodesmium - effect of temperature on diazotrophy, Biogeosciences, 4, 53-61, doi:10.5194/bg-4-53-2007, 2007.

Broadgate, W. J., Malina, G., Küpper, F. C., Thompson, A., and Liss, P. S.: Isoprene and other non-methane hydrocarbons from seaweeds: a source of reactive hydrocarbons to the atmosphere, Mar. Chem., 88, 61-73, doi:10.1016/j.marchem.2004.03.002, 2004.

Bullister, J. L., Guinasso, N. L., and Schink, D. R.: Dissolved hydrogen, carbon monoxide and methane at the CEPEX site, J. Geophys. Res., 87, 2022-2034, 1982.

Capone, D. G., Zehr, J. P., Paerl, H. W., Bergman, B., and Carpenter, E. J.: Trichodesmium, a globally significant marine cyanobacterium, Science, 276, 1221-1229, doi:10.1126/science.276.5316.1221, 1997.

Capone, D. G., Burns, J. A., Montoya, J. P., Subramaniam, A., Mahaffey, C., Gunderson, T., Michaels, A. F., and Carpenter, E. J.: Nitrogen fixation by Trichodesmium spp.: An important source of new nitrogen to the tropical and subtropical 
North Atlantic Ocean, Global Biogeochem. Cy., 19, GB2024, doi:10.1029/2004GB002331, 2005.

Conrad, R.: Biogeochemistry and ecophysiology of atmospheric $\mathrm{CO}$ and $\mathrm{H}_{2}$, Adv. Microb. Ecol., 10, 231-283, 1988.

Conrad, R. and Seiler, W.: Methane and hydrogen in seawater (Atlantic Ocean), Deep-Sea Res., 35, 1903-1917, 1988.

Dahdouh-Guebas, F. and Koedam, N.: Are the northernmost mangroves of West Africa viable? - a case study in Banc d'Arguin National Park, Mauritania, Hydrobiologia, 458, 241-253, 2001.

Davis, C. S., and McGillicuddy, D. J.: Transatlantic abundance of the $\mathrm{N}_{2}$-fixing colonial cyanobacterium Trichodesmium, Science, 312, 1517-1520, doi:10.1126/science.1123570, 2006.

Deutsch, C., Sarmiento, J. L., Sigman, D. M., Gruber, N., and Dunne, J. P.: Spatial coupling of nitrogen inputs and losses in the ocean, Nature, 445, 163-167, doi:10.1038/nature05392, 2007.

Draxler, R. R. and Rolph, G. D.: HYSPLIT (HYbrid Single-Particle Lagrangian Integrated Trajectory) Model access via NOAA ARL READY Website (http://ready.arl.noaa.gov/HYSPLIT. php), NOAA Air Resources Laboratory, Silver Spring, MD, 2013.

Ehhalt, D. H. and Rohrer, F.: The tropospheric cycle of $\mathrm{H}_{2}$ : a critical review, Tellus B, 61, 500-535, 2009.

Falcón, L. I., Cipriano, F., Chistoserdov, A. Y., and Carpenter, E. J.: Diversity of diazotrophic unicellular cyanobacteria in the tropical North Atlantic Ocean, Appl. Environ. Microb., 68, 5760-5764, doi:10.1128/AEM.68.11.5760.2002, 2002.

Falcón, L. I., Carpenter, E. J., Cipriano, F., Bergman, B., and Capone, D. G.: $\mathrm{N}_{2}$ fixation by unicellular bacterioplankton from the Atlantic and Pacific Oceans?: Phylogeny and in situ rates, Appl. Environ. Microb., 70, 765-770, doi:10.1128/AEM.70.2.765-770.2004, 2004

Feck, T., Grooß, J.-U., and Riese, M.: Sensitivity of Arctic ozone loss to stratospheric $\mathrm{H}_{2} \mathrm{O}$, Geophys. Res. Lett., 35, L01803, doi:10.1029/2007GL031334, 2008.

Feilberg, K. L., Johnson, M. S., Bacak, A., Röckmann, T., and Nielsen, C. J.: Relative tropospheric photolysis rates of HCHO and HCDO measured at the European photoreactor facility, J. Phys. Chem. A, 111, 9034-9046, 2007.

Fernández, A., Mouriño-Carballido, B., Bode, A., Varela, M., and Marañón, E.: Latitudinal distribution of Trichodesmium spp. and N2 fixation in the Atlantic Ocean, Biogeosciences, 7, 31673176, doi:10.5194/bg-7-3167-2010, 2010.

Gerst, S. and Quay, P.: Deuterium component of the global molecular hydrogen cycle, J. Geophys. Res., 106, 5021-5031, 2001.

Hagen, E.: Northwest African upwelling scenario, Oceanol. Acta, 24, S113-S128, 2001.

Hauglustaine, D. A. and Ehhalt, D. H.: A three-dimensional model of molecular hydrogen in the troposphere, J. Geophys. Res., 107, 4330-4346, doi:10.1029/2001JD001156, 2002.

Herr, F. L.: Dissolved hydrogen in Eurasian Arctic waters, Tellus, 36B, 55-66, 1984.

Herr, F. L., Scranton, M. I., and Barger, W. R.: Dissolved hydrogen in the Norwegian Sea: Mesoscale surface variability and deepwater distribution, Deep-Sea Res., 28A, 1001-1016, 1981.

Herr, F. L., Frank, E. C., Leone, G. M., and Kennicutt, M. C.: Diurnal variability of dissolved molecular hydrogen in the tropical South Atlantic Ocean, Deep-Sea Res., 31, 13-20, 1984.

Jacobson, M. Z.: Effects of wind-powered hydrogen fuel cell vehicles on stratospheric ozone and global climate, Geophys. Res.
Lett., 35, L19803, doi:10.1029/2008GL035102, 2008.

Jacobson, M. Z., Colella, W. G., and Golden, D. M.: Cleaning the air and improving health with hydrogen fuel-cell vehicles, Science, 308, 1901-1905, 2005.

Jordan, A. and Steinberg, B.: Calibration of atmospheric hydrogen measurements, Atmos. Meas. Tech., 4, 509-521, doi:10.5194/amt-4-509-2011, 2011.

Karl, D., Michaels, A., Bergman, B., Capone, D., Carpenter, E., Letelier, R., Lipschultz, F., Paerl, H., Sigman, D., and Stal, L.: Dinitrogen fixation in the world's oceans, Biogeochemistry, 57/58, 47-98, 2002.

Kars, G., Gündüz, U., Yücel, M., Rakhely, G., Kovacs, K. L., and Eroğlu, İ.: Evaluation of hydrogen production by Rhodobacter sphaeroides O.U.001 and its hupSL deficient mutant using acetate and malate as carbon sources, Int. J. Hydrogen Energ., 34, 2184-2190. doi:10.1016/j.ijhydene.2009.01.016, 2009.

Klap, V. A., Hemminga, M. A., and Boon, J. J.: Retention of lignin in seagrasses: angiosperms that returned to the sea, Mar. Ecol.Prog. Ser., 194, 1-11, 2000.

Knox, M., Quay, P. D., and Wilbur, D.: Kinetic isotopic fractionation during air-water gas transfer of $\mathrm{O}_{2}, \mathrm{~N}_{2}, \mathrm{CH}_{4}$, and $\mathrm{H}_{2}$, $\mathrm{J}$. Geophys. Res., 97, 20335-20343, 1992.

Kock, A., Gebhardt, S., and Bange, H. W.: Methane emissions from the upwelling area off Mauritania (NW Africa), Biogeosciences, 5, 1119-1125, doi:10.5194/bg-5-1119-2008, 2008.

Millet, D. B., Guenther, A., Siegel, D. A., Nelson, N. B., Singh, H. B., de Gouw, J. A., Warneke, C., Williams, J., Eerdekens, G., Sinha, V., Karl, T., Flocke, F., Apel, E., Riemer, D. D., Palmer, P. I., and Barkley, M.: Global atmospheric budget of acetaldehyde: 3-D model analysis and constraints from in-situ and satellite observations, Atmos. Chem. Phys., 10, 3405-3425, doi:10.5194/acp-10-3405-2010, 2010.

Minas, H. J., Codispoti, L. A., and Dugdale, R. C.: Nutrients and primary production in the upwelling region off Northwest Africa, edited by: Rapp, P.-V., Réun. Cons. Int. Explor. Mer, 180, 148183, 1982.

Mittelstaedt, E.: The upwelling area off Northwest Africa - A description of phenomena related to coastal upwelling, Prog. Oceanogr., 12, 307-331, doi:10.1016/0079-6611(83)90012-5, 1983.

Monod, T.: Le Pare National du Banc d'Arguin et l'histoire, le cadre general, flore et vegetation du PNBA, in: Association de soutien du Pare National du Banc d'Arguin, Richesse du Pare National du Banc d'Arguin (Mauritanie), Versailles, 1977.

Montoya, J. P., Voss, M., and Capone, D. G.: Spatial variation in $\mathrm{N}_{2}$-fixation rate and diazotroph activity in the Tropical Atlantic, Biogeosciences, 4, 369-376, doi:10.5194/bg-4-369-2007, 2007.

Moore, R. M., Punshon, S., Mahaffey, C., and Karl, D.: The relationship between dissolved hydrogen and nitrogen fixation in ocean waters, Deep-Sea Res., 56, 1449-1458, doi:10.1016/j.dsr.2009.04.008, 2009.

Muccitelli, J. and Wen, W.-Y.: Solubilities of hydrogen and deuterium gases in water and their isotope fractionation factor, J. Sol. Chem., 7, 257-266, 1978.

Nilsson, E. J. K., Johnson, M. S., Taketani, F., Matsumi, Y., Hurley, M. D., and Wallington, T. J.: Atmospheric deuterium fractionation: $\mathrm{HCHO}$ and $\mathrm{HCDO}$ yields in the $\mathrm{CH}_{2} \mathrm{DO}+\mathrm{O}_{2}$ reaction, Atmos. Chem. Phys., 7, 5873-5881, doi:10.5194/acp-7-5873-2007, 2007. 
Nilsson, E. J. K., Andersen, V. F., Skov, H., and Johnson, M. S.: Pressure dependence of the deuterium isotope effect in the photolysis of formaldehyde by ultraviolet light, Atmos. Chem. Phys., 10, 3455-3462, doi:10.5194/acp-10-3455-2010, 2010.

Novelli, P. C., Lang, P. M., Masarie, K. A., Hurst, D. F., Myers, R., and Elkins, J. W.: Molecular hydrogen in the troposphere: Global distribution and budget, J. Geophys. Res., 104, $30427-$ 30444, 1999.

Pieterse, G., Krol, M. C., and Röckmann, T.: A consistent molecular hydrogen isotope chemistry scheme based on an independent bond approximation, Atmos. Chem. Phys., 9, 8503-8529, doi:10.5194/acp-9-8503-2009, 2009.

Pieterse, G., Krol, M. C., Batenburg, A. M., Steele, L. P., Krummel, P. B., Langenfelds, R. L., and Röckmann, T.: Global modelling of $\mathrm{H}_{2}$ mixing ratios and isotopic compositions with the TM5 model, Atmos. Chem. Phys., 11, 7001-7026, doi:10.5194/acp-11-70012011, 2011.

Pieterse, G., Krol, M.C., Batenburg, A.M., Brenninkmeijer, C. A. M., Popa, M. E., O’Doherty, S., Grant, A., Steele, L. P., Krummel, P. B., Langenfels, R.L., Wang, H.J., Vermeulen, A.T. Schmidt, M., Yver, C., Jordan, A., Engel, A., Fisher, R.E., Lowry, D., Nisbet, E. G., Reimann, S., Vollmer, M. K., Steinbacher,, M., Hammer, S., Forster, G., Sturges, W. T., and Röckmann, T.: Reassessing the variability in atmospheric $\mathrm{H}_{2}$ using the two-way nested TM5 model, in press, doi:10.1002/jgrd.50204, 2013.

Prather, M. J.: An environmental experiment with $\mathrm{H}_{2}$ ?, Science, 302, 581-582, 2003.

Punshon, S. and Moore, R.: Photochemical production of molecular hydrogen in lake water and coastal seawater, Mar. Chem., 108, 215-220, doi:10.1016/j.marchem.2007.11.010, 2008a.

Punshon, S. and Moore, R. M.: Aerobic hydrogen production and dinitrogen fixation in the marine cyanobacterium Trichodesmium erythraeum IMS101, Limnol. Oceanogr., 53, 2749-2753, 2008 b.

Punshon, S., Moore, R. M., and Xie, H.: Net loss rates and distribution of molecular hydrogen $\left(\mathrm{H}_{2}\right)$ in mid-latitude coastal waters, Mar. Chem., 105, 129-139, doi:10.1016/j.marchem.2007.01.009, 2007.

Rahn, T., Kitchen, N., and Eiler, J. M.: D/H ratios of atmospheric $\mathrm{H}_{2}$ in urban air: Results using new methods for analysis of nanomolar $\mathrm{H}_{2}$ samples, Geochim. Cosmochim. Ac., 66, 2475-2481, 2002.

Rahn, T., Eiler, J. M., Boering, K. A., Wennberg, P. O., McCarthy, M. C., Tyler, S., Schauffler, S., Donnelly, S., and Atlas, E.: Extreme deuterium enrichment in stratospheric hydrogen and the global atmospheric budget of $\mathrm{H}_{2}$, Nature, 424, 918-921, 2003.

Rhee, T. S., Mak, J., Röckmann, T., and Brenninkmeijer, C. A. M.: Continuous-flow isotope analysis of the deuterium/hydrogen ratio in atmospheric hydrogen, Rapid Commun. Mass Sp., 18, 299 306, doi:10.1002/rcm.1309, 2004.

Rhee, T. S., Brenninkmeijer, C. A. M., Braß, M., and Brühl, C.: Isotopic composition of $\mathrm{H}_{2}$ from $\mathrm{CH}_{4}$ oxidation in the stratosphere and the troposphere, J. Geophys.Res., 111, D23303, doi:10.1029/2005JD0006760, 2006a.

Rhee, T. S., Brenninkmeijer, C. A. M., and Röckmann, T.: The overwhelming role of soils in the global atmospheric hydrogen cycle, Atmos. Chem. Phys., 6, 1611-1625, doi:10.5194/acp-61611-2006, 2006b.

Rice, A., Quay, P., Stutsman, J., Gammon, R., Price, H., and Jaegle, L.: Meridional distribution of molecular hydrogen and its deuterium content in the atmosphere, J. Geophys. Res., 115, D12306, doi:10.1029/2009JD012529, 2010.

Röckmann, T., Rhee, T. S., and Engel, A.: Heavy hydrogen in the stratosphere, Atmos. Chem. Phys., 3, 2015-2023, doi:10.5194/acp-3-2015-2003, 2003.

Röckmann, T., Gómez Álvarez, C. X., Walter, S., van Veen, C., Wollny, A. G., Gunthe, S. S., Helas, G., Pöschl, U., Keppler, F., Greule, M., and Brand, W. A.: The isotopic composition of $\mathrm{H}_{2}$ from wood burning - dependency on combustion efficiency, moisture content and $\delta \mathrm{D}$ of local precipitation, J. Geophys. Res., 115, D17308, doi:10.1029/2009JD013188, 2010a.

Röckmann, T., Walter, S., Bohn, B., Wegener, R., Spahn, H., Brauers, T., Tillmann, R., Schlosser, E., Koppmann, R., and Rohrer, F.: Isotope effect in the formation of $\mathrm{H}_{2}$ from $\mathrm{H}_{2} \mathrm{CO}$ studied at the atmospheric simulation chamber SAPHIR, Atmos. Chem. Phys., 10, 5343-5357, doi:10.5194/acp-10-53432010, 2010b.

Rothe, M., Jordan, A., and Brand, W. A.: Trace gases, $\delta^{13} \mathrm{C}$ and $\delta^{18} \mathrm{O}$ of $\mathrm{CO}_{2}$-in-air samples: Storage in glass flasks using PCTFE seals and other effects, in: GAW report 161,12th WMO/IAEA meeting of experts on carbon dioxide concentration and related tracers measurements techniques, edited by: Worthy, D. and Huang, L., Toronto, Canada, 15-18 September 2003, WMOTD No. 1275, 2004.

Schaffmeister, B., Hiddink, J., and Wolff, W.: Habitat use of shrimps in the intertidal and shallow subtidal seagrass beds of the tropical Banc d'Arguin, Mauritania. J. Sea Res., 55, 230-243, doi:10.1016/j.seares.2005.10.003, 2006.

Schlitzer, R.: Ocean Data View 4, http://odv.awi.de, 2012.

Schmidt, U.: The latitudinal and vertical distribution of molecular hydrogen in the troposphere, J. Geophys. Res., 83, 941-946, doi:10.1029/JC083iC02p00941, 1978.

Schultz, M. G., Diehl, T., Brasseur, G. P., and Zittel, W.: Air pollution and climate-forcing impacts of a global hydrogen economy, Science, 302, 624-627, 2003.

Schütz, K., Happe, T., Troshina, O., Lindblad, P., Leitão, E., Oliveira, P., and Tamagnini, P.: Cyanobacterial $\mathrm{H}_{2}$ production - a comparative analysis, Planta, 218, 350-359, doi:10.1007/s00425003-1113-5, 2004.

Scranton, M. I.: The role of the cyanobacterium Oscillatoria (Trichodesmium) thiebautii in the marine hydrogen cycle, Mar. Ecol., 11, 79-87, 1983.

Scranton, M., Jones, M., and Herr, F.L.: Distribution and variability of hydrogen in the Mediterranean Sea, J. Mar. Res., 40, 873-891, 1982.

Seiler, W. and Schmidt, U.: Dissolved non-conservative gases in seawater. in: The sea, edited by: Goldberg, E. D., John Wiley \& Sons, New York, 5, 219-243, 1974.

Setser, P. J., Bullister, J. L., Frank, E. C., Guinasso, N. L., and Schink, D. R.: Relationships between reduced gases, nutrients, and fluorescence in surface waters off Baja California, Deep-Sea Res., 29, 1203-1215, 1982.

Sevrin-Reyssac, J.: Hydrology and underwater climate of the Banc d 'Arguin , Mauritania?: a review, Hydrobiologia, 258, 1-8, 1993.

Siegel, D. A., Maritorena, S., Nelson, N. B., Hansell, D. A., and Lorenzi-Kayser, M.: Global distribution and dynamics of colored dissolved and detrital organic materials, J. Geophys. Res., 107, 3228, doi:10.1029/2001JC000965, 2002. 
Signorini, S. R., Murtugudde, R. G., McClain, C. R., Christian, J. R., Picaut, J., and Busalachhi, A. J.: Biological and physical signatures in the tropical and equatorial Atlantic, J. Geophys. Res., 104, 18367-18382, 1999.

Singh, H. B., Salas, L. J., Chatfield, R. B., Czech, E., Fried, A., Walega, J., Evans, M. J., Field, B. D., Jacob, D. J., Blake, D., Heikes, B., Talbot, R., Sachse, G., Crawford, J. H., Avery, M. A., Sandholm, S., and Fuelberg, H.: Analysis of the atmospheric distribution, sources, and sinks of oxygenated volatile organic chemicals based on measurements over the Pacific during TRACE-P, J. Geophys. Res., 109, D15S07, doi:10.1029/2003JD003883, 2004.

Sinha, V., Williams, J., Meyerhöfer, M., Riebesell, U., Paulino, A. I., and Larsen, A.: Air-sea fluxes of methanol, acetone, acetaldehyde, isoprene and DMS from a Norwegian fjord following a phytoplankton bloom in a mesocosm experiment, Atmos. Chem. Phys., 7, 739-755, doi:10.5194/acp-7-739-2007, 2007.

Smith-Downey, N. V., Randerson, J. T., and Eiler, J. M.: Molecular hydrogen uptake by soils in forest, desert, and marsh ecosystems in California, J. Geophys. Res., 113, 1-11, doi:10.1029/2008JG000701, 2008.

Tamagnini, P., Leitão, E., Oliveira, P., Ferreira, D., Pinto, F., Harris, D. J., Heidorn, T., and Lindblad, P.: Cyanobacterial hydrogenases: diversity, regulation and applications, FEMS Microbiol. Rev., 31, 692-720, doi:10.1111/j.1574-6976.2007.00085.x, 2007.

Thoss, V., Baird, M. S., Lock, M. A., and Courty, P. V.: Quantifying the phenolic content of freshwaters using simple assays with different underlying reaction mechanisms, J. Environ. Monitor., 4, 270-275, doi:10.1039/b107573j, 2002.

Torbatinejad, N. M., Annison, G., Rutherfurd-Markwick, K., and Sabine, J. R.: Structural constituents of the seagrass Posidonia australis, J. Agr. Food Chem., 55, 4021-4026, doi:10.1021/jf063061a, 2007.

Tromp, T. K., Shia, R.-L., Allen, M., Eiler, J. M., and Yung, Y. L.: Potential environmental impact of a hydrogen economy on the stratosphere, Science, 300, 1740-1742, 2003.

Tyrrell, T., Maranon, E., Poulton, A. J., Bowie, A. R., Harbour, D. S., and Woodward, E. M. S.: Large-scale latitudinal distribution of Trichodesmium spp. in the Atlantic Ocean, J. Plankton Res., 25, 405-416, 2003.

Vignais, P. M.: H/D exchange reactions and mechanistic aspects of the hydrogenases, Coordin. Chem. Rev., 249, 1677-1690, doi:10.1016/j.ccr.2005.01.026, 2005.

Vollmer, M. K., Walter, S., Bond, S. W., Soltic, P., and Röckmann, T.: Molecular hydrogen $\left(\mathrm{H}_{2}\right)$ emissions and their isotopic signatures (H/D) from a motor vehicle: implications on atmospheric H2, Atmos. Chem. Phys., 10, 5707-5718, doi:10.5194/acp-105707-2010, 2010.
Voss, M. Croot, P., Lochte, K., Mills, M., and Peeken, I.: Patterns of nitrogen fixation along $10^{\circ} \mathrm{N}$ in the tropical Atlantic, Geophys. Res. Lett., 31, 7-10. doi:10.1029/2004GL020127, 2004.

Walter, S., Laukenmann, S., Stams, A. J. M., Vollmer, M. K., Gleixner, G., and Röckmann, T.: The stable isotopic signature of biologically produced molecular hydrogen $\left(\mathrm{H}_{2}\right)$, Biogeosciences, 9, 4115-4123, doi:10.5194/bg-9-4115-2012, 2012.

Warwick, N. J., Bekki, S., Nisbet, E. G., and Pyle, J. A.: Impact of a hydrogen economy on the stratosphere and troposphere studied in a 2-D model, Geophys. Res. Lett., 31, L05107, doi:10.1029/2003GL019224, 2004.

Wilson, S. T., Foster, R. A., Zehr, J. P., and Karl, D. M.: Hydrogen production by Trichodesmium erythraeum, Cyanothece sp., and Crocosphaera watsonii, Aquat. Microb. Ecol., 59, 197-206, doi:10.3354/ame01407, 2010a.

Wilson, S. T., Tozzi, S., Foster, R. A., Ilikchyan, I., Kolber, Z. S., Zehr, J. P., and Karl, D. M.: Hydrogen cycling by the unicellular marine diazotroph Crocosphaera watsonii strain WH8501, Appl. Environ. Microb., 76, 6797-803, doi:10.1128/AEM.01202-10, $2010 b$.

Wolff, W. J., Land, J., Nienhuis, P. H., and Wilde, P. A. W. J.: The functioning of the ecosystem of the Banc d'Arguin, Mauritania: a review. Hydrobiologia, 258, 211-222, doi:10.1007/BF00006198, 1993.

Zehr, J. P., Waterbury, J. B., Turner, P. J., Montoya, J. P., Omoregie, E., Steward, G. F., Hansen, A., and Karl, D. M.: Unicellular cyanobacteria fix $\mathrm{N}_{2}$ in the subtropical North Pacific Ocean. Nature, 412, 635-638, 2001.

Zepp, R. G., Callaghan, T. V., and Erickson, D. J.: Effects of enhanced solar ultraviolet radiation on biogeochemical cycles, J. Photoch. Photobio. B, 46(1-3), 69-82. doi:10.1016/S10111344(98)00186-9, 1998.

Zhou, X. and Mopper, K.: Photochemical production of lowmolecular-weight carbonyl compounds in seawater and surface microlayer and their air-sea exchange, Mar. Chem., 56, 201-213, 1997.

Zindler, C., Peeken, I., Marandino, C. A., and Bange, H. W.: Environmental control on the variability of DMS and DMSP in the Mauritanian upwelling region, Biogeosciences, 9, 1041-1051, doi:10.5194/bg-9-1041-2012, 2012. 